DOI 10.4467/2543733XSSB.17.025.8323

DRAGICA POPOVSKA

Institute of National History, Skopje

\title{
SYMBOLIC REPRESENTATIONS OF IDENTITY AND THE HISTORY OF THE JEWS IN MACEDONIA'S PUBLIC SPACE
}

Key words: Macedonian Jews, public space, symbolic representation, identity.

Space and identity interact with each other by means of symbols. Symbolic forms in a public space as material representations are inevitably associated with intangible manifestations such as emotions, values, ideas... ${ }^{1}$ If we keep in mind that identity (in this context and identity of a place) is not only an emotive category but also a psychodynamic process, socially structured ${ }^{2}$, it is clear that symbolic forms' interpretations are dependent on the context in which they appear and in which they persist.

"Symbolic representation stands for the representation of a group, nation or state through an 'object', to which a certain representative meaning is attributed"3. This paper focuses on the symbolic representations of Jews in Macedonia, i.e. "facilities" that express their identity and history and allow their visibility in the public space. I am speaking here not only of monuments and museums but also for settlements and other symbols that created / create the image of the Jews in Macedonia through time. The goal is to answer a few questions: What are the symbols that represent Jewish history and culture in the public sphere? What do these symbols tell us? What meanings or what emotions do they evoke in people? Of course, the discursive dimension of symbolic representations is very important, especially the socially constructed role which is attributed to those facilities. In accordance with these approaches, the construction of an identity as one of the key functions of symbolic representation takes place within the socially placed narratives

1 J. Monnet, The symbolism of place: a geography of relationships between space, power and identity, Politique, Culture, Représentation, Cubergeo - European Journal of Geography, 2011, https://cybergeo.revues. org/24747, (date accessed:14.01.2017).

2 S. Clarke, Culture and Identity, in: The SAGE Handbook of Cultural Analysis, 2008, SAGE Publications, 8. Aug. 2001, p. 511.

${ }^{3}$ P. Meier, E. Lo mbardo, Symbolic representation and the construction of gender roles in the European Union, Paper for the AECPA Conference, Murcia, 7-9 September 2011, (date accessed: 25.09.2016).

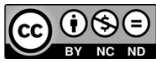


of the Jews, which means its dynamics and variables is directly related to social events, political changes, etc.

The Jews in Macedonia were populated mainly in the central areas of cities: Skopje ${ }^{4}$, Stip, and Bitola ${ }^{5}$. The long-term of living of this population in these areas has contributed to their being recognized as places filled with "Jewish values," "Jewish way of life", etc., due to this they have been named as "Evrejski maala" ("Jewish neighborhoods/places"). This is because the term "place" refers to the physical environment in the context of social, psychological and cultural meanings attached to it ${ }^{6}$. Simply, the way of interaction between people and place have implications on its definition as such. For the perception of specific places as "Jewish", physical parameters such as the existence of synagogues, Jewish schools and so on are of great importance for this ${ }^{7}$. These facilities, along with their specifics in the way of dressing, food, religious beliefs etc., contributed to the physical space to become a "place" where Jewish culture and presence is expressed.

A place or its identity becomes a cognitive "database", through which the Jewish community perceives itself, while this database has an influence in defining the perceptions among "others". Hence, these places at the concrete time are treated as a social marker or symbol of Judaism in the city.

After the deportation of the Jews, in March $1943^{8}$, these neighborhoods began to lose their "Jewish" identity. Simply put, without their residents, "Jewishness" in specific areas

4 Jewish quarter (Evrejsko maalo) or "Čivutana" as it is also called, extended from Kale toward Vardar and Old Bazar (Stara čaršija), from the church St. Demetrius until to the end of the city, despite age, over a Stone bridge (Kamen most). (See: К. Дојчиноски, Скопје-паралели, Матица Македонска, Скопје, 1999, 109. For Jewish quarter see also: А. Качева, С. Христова, Т. Ѓорѓиовска, Животот во Скопје 1918-1941, Музеј на град Скопје Скопје 2002, 27.

5 Before the World War II there were nearly 8000 Jews in Bitola and some 3000 Jews in Skopje. (Zh. D a s k a lov s k i, Remembering the Past, Central Europe Review, Vol. 2, No. 4, 31 January 2000. (date accessed: 08.05.2017). Number of Jews in Štip were some 550 (Mark C o h e n, The Holocaust in Macedonia: Deportation of Monastir Jewry, Holocaust Encyclopedia, United States Holocaust Memorial Museum (date accessed: 08.05.2017).

${ }^{6}$ See: H. Ashild L a p pegard, Identity and place: a critical comparison of three identity theories, Architectural Science Review, March 1, 2007, http:/www.highbeam.com/DocPrint.aspx?DocId=1G1:160922464 (date accessed: 27.09.2016).

7 See: Ј. Х Ш и-В а с и љ в и ћ, Скопље и његова околина (историска, етнографска и културно-политичка излагања), Штампарија „Св. Сава“, Београд 1930, pp. 66.

${ }^{8}$ After the occupation of 1941, Germany surrendered her control in the hands of Bulgaria, which became the occupier of the largest part of Vardar Macedonia. Already in 1943 this country began the deportation of Macedonian Jews to death camps in Poland, which was under German occupation. On March 11, 1943 year, in Tobacco in Skopje was collected Jews from Skopje, Bitola, Štip with aim to be sent to Treblinka. Then about 7,200 Macedonian Jews were killed in gas chambers in the death camp. Here's how a Jewish woman survivor, who now lives in Israel remembers this day: "The soldierss came with rifle, knocking on the door. They told us: fast, fast, for half an your're down. They told us not take a lot of things, you do not need them. When we left the house we saw that the street was full of people and more and more people were coming out of the houses. We all headed to the train station. When we got there they took away everything: earrings, rings and watches and there was a nice, detailed examination. They took us to Monopol (Tobacco) in Skopje" - these are the words of Šela Sion Alterac, one of the surviving Jews during deportation to the death camp Treblinka. This woman, the child - witness, was saved by her sister who lived in Pristina. See: „Сведоштво на преживеана македонска Еврејка: „Ме разделија од мајка ми, мислев тоа е крај за мене“, http://kanal77.mk (date accessed: 15.01.2017). 
becomes less visible or invisible . Former cultural symbols, markers of Jewish ethnic and religious affiliation, such as synagogues, schools, houses, etc. for those who remained became symbols of sadness and pity for the neighbors, "face-off" with the events that took place here. On the other hand, the physical space undergoing change over time, which strongly influences decreasing the intensity to the already existing associations with places.

After liberation, in the changed socio-political circumstances, placement of monuments in public space marks the deportation of the Macedonian Jews. The tobacco facility (Monopol) is a place that reminds of terror and resets the memory of the victims. Therefore, a plaque was placed on one of the buildings of Skopje's Tobacco as a collection point from where the Jews went to Treblinka. In this site, the monument is placed in a horticultural solved space. In 1985, the "Monument to the Deported Jews" of that city was erected in Stip ${ }^{10}$.

These memorials and monuments bear witness to the spirit of the new age and the change of social attitude towards the Jews. The Jewwish absence in cities, now through monumental figural representations passes into eternity, exactly through memory.

In independent Macedonia, initiatives to raise monuments to the Jews continue. As the technique of collective memory, it creates a toponomy, which acts as intermediaries between time and eternity, which certainly talk about current social tendencies and ideas. Death, through monuments, used to convict the act and to propagate the idea of "forever remembered, but never forgotten." In this context, a monument to the Jews erected in Bitola, and the site of the Jewish cemetery are planning to be rearranged into a memorial park for the Jews of Monastir. In Skopje, in 2005, the monument "Symphony of Peace" dedicated to victims of the Holocaust in Macedonia was discovered ${ }^{11}$. According to the author, it is the "antithesis of the horrors of war and the madness it brings with itself"12.

The same year, the foundation stone of the Museum of the Holocaust Memorial Center in Macedonia was laid, which was opened in $2011^{13}$. Bearing in mind that it is

${ }^{9}$ Here's how Gjorgi H. remembers the Jews and the events associated with them in the city of Štip: "They destroyed Jewish houses. There was a committee made up of our local people, from Štip. Every day I watched the sale of Jewish subjects on the market. One of the committee members showed a piece of furniture, of a chair, for example, and then the crowd started bidding. There were Bulgarians who supervised the sale, in case someone wanted to sell something for a price lower than its value. And one day it stopped. No Jewish houses, no Jewish subjects, just memories. Everything was empty around me". See more in: Ж. Коло м он ос, В. В е с ко в и ќВ а н ге л и, Евреите во Македонија (1941-1945), Зборник на документи, том I, II, Македонска академија на науки и уметности, Скопје 1986.

${ }_{10}$ The monument is the work of the Metodi Andonov and symbolized the life path of the Jews. The line of life is interrupted on March 11, 1943, when 551 people were deported from Štip and killed in the Treblinka death camp. The monument is located next to the building of the Zavod i Muzej - Štip. See: Споменик на Евреите, Општина Штип, http://stip.gov.mk/index.php/mk/profil/kultura/301-2009-12-10-10-16-28 (date accessed: 15.01. 2017).

11 The monument is located on the square "Sloboda", as an art of Tome Serafimovski. It represents a bronze sculpture of three birds - pigeons standing on the earth globe. See: Е. А л е к и е в, Бронзена тивка и ненаметлива поетика, Дневник, 2719, 18 март 2006, http://star.dnevnik.com.mk/default.aspx?pbroj=2719\&stID=51910 (date accessed: 15.01.2017).

12 Ibidem.

${ }^{13}$ М. А в и, Х. Козм а, Поставен камен-темелникот на меморијалниот Центар на Холокаустот на Евреите (02.09.2005 godina), Билтен за меѓународна соработка, бр. 5. In 2002 this area was returned to Jews as the property without legal heirs. 


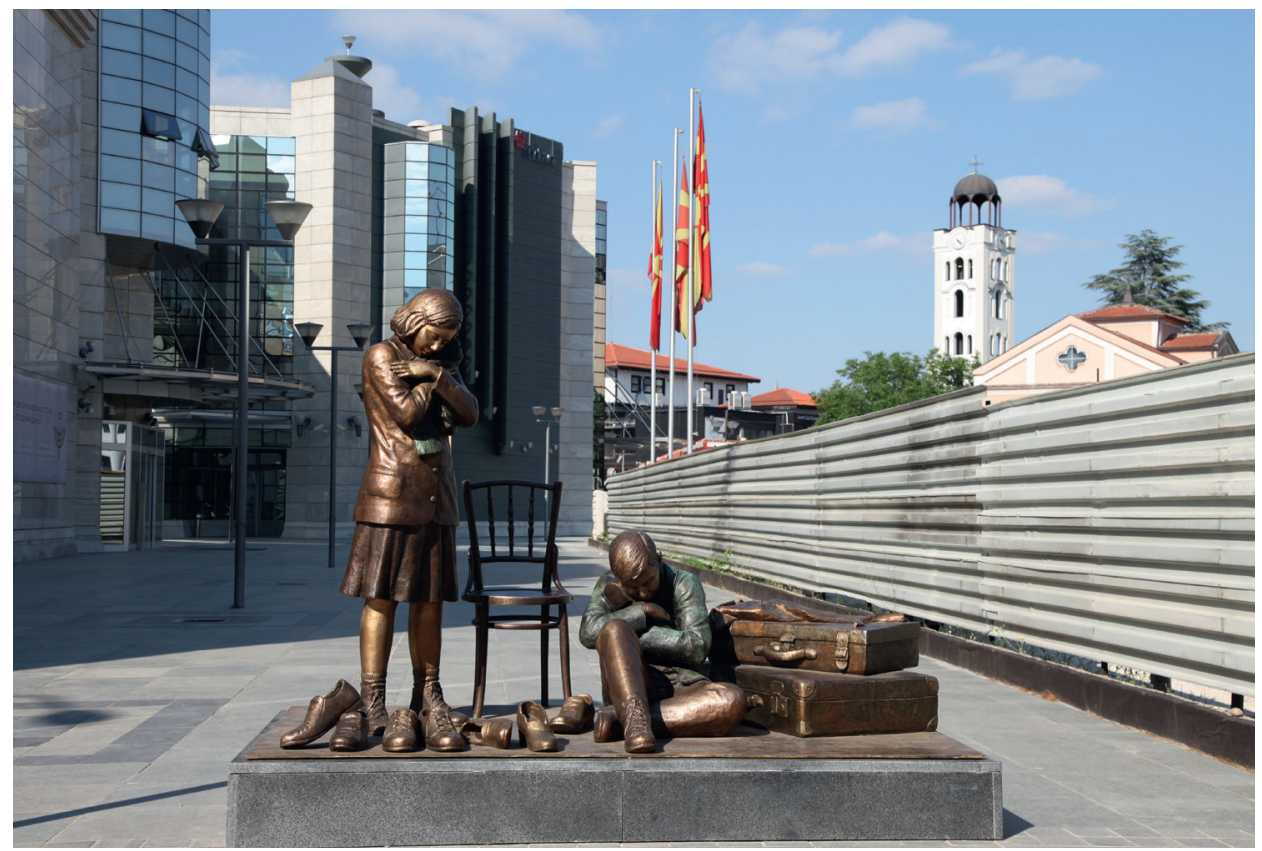

Monument to Jewish victims in Macedonia as a sign of remembrance of the uprising of the Jews in the Warsaw ghetto in 1943, in Skopje. Photo Maciej Kawka

located on the place of the former Jewish neighborhood, its appearance could be seen as a transformed image of the site where Jews once lived. Thanks to the museum, the Jewish neighborhood comes alive again as part of today, constituting the discourse through which Jews historically framed themselves and their relationships not only with the former Jewish neighborhood in Skopje but also with other ethnic groups, with whom the Jewish ethnic group built relationships in everyday communication ${ }^{14}$. The presence of the museum in the space not only strengthens the identification of visitors with the time and place of events but in terms of symbolism, it practically integrates the current Macedonian Jews ${ }^{15}$ in the center of the former "fireplace" - exactly through the museum as an $\operatorname{artifact}^{16}$. In 2015, near the museum, a monument to Jewish victims in Macedonia was unveiled, as a sign of remembrance of the uprising of the Jews in the Warsaw ghetto in 1943.

The setting of the mentioned monuments and museum in the public space aims, through forms of the memory of the Jews and the Holocaust, previously aggressive and not human ideology to gain a powerful alternative: a new world that respects universal human values. They are symbols through which the image of historical reality, seen through

${ }^{14}$ Д. По по в с ка, Музејот на холокаустот во Скопје: место на сеќавање, Историја, Здружение на историчарите на PM, XLIX,1, Скопје 2014, pp. 281-290.

15 About 200 Jews live in Macedonia today.

16 See more in: Д. По п в с ка, Музејот на холокаустот во Скопје: место на сеќавање, во Историја, Здружение на историчарите на PM, XLIX, 1, Скопје 2014, pp. 281-290. 
the prism of today's society is reproduced, thus preventing social amnesia, because monuments mean emotional "contact" with the events of 1943.

At the same time, their raising means establishing a continuity with the time in which the Jews existed. In the absence of people, monuments, as material representations in the public space become an identification cultural field of the "Jewishness". It can be said that they are "a concrete sign that evokes", "something that is absent or impossible for perception" ${ }^{\prime 17}$. They are toponyms of Jewish identity, places of gathering, and they appear in the role of intermediaries between time and eternity. They offer solace to the minority of the Jews who remained ${ }^{18}$, that their deceased are honored with eternal remembrance, while as "monuments of events" educate others not only about current social values and requirements but also about the history of the Jews.

Hence, the selected "places" are perceived as a social marker of Jewish identity in Macedonia, symbols that express the changes that have occurred in this community. For ethnicity that survived cataclysmic events throughout history, the existence of such monuments or symbols is a very important aspect of identity, because they contribute to the "survival" or maintenance of the group, especially after the events of 1943. Their symbolic meaning, on the one hand, supports cohesion in the Jewish community, which guarantees a shared identity, and on the other hand the legitimate Jewish presence in the space, which makes it visible to "others".

\section{Bibliography}

Clarke Simon, Culture and Identity, The SAGE Handbook of Cultural Analysis, 2008, SAGE Publications, 8. Aug. 2001.

Cohen Mark, The Holocaust in Macedonia: Deportation of Monastir Jewry, Holocaust Encyclopedia, United States Holocaust Memorial Museum. Availible at: https://www.ushmm.org/wlc/en/ article.php?ModuleId=10006804.

Daskalovski Zhidas, Remembering the Past, Central Europe Review, Vol. 2, No. 4, 31 January 2000. Available at: http://www.ce-review.org/00/4/daskalovski4.html

Meier Petra, Lombardo Emanuela, Symbolic representation and the construction of gender roles in the European Union, Paper for the AECPA Conference, Murcia, 7-9 September 2011.

Monnet Jérôme, The symbolism of place: a geography of relationships between space, power and identity, Politique, Culture, Représentation, Cubergeo - European Journal of geography, 2011, https://cybergeo.revues.org/24747.

Ави М., Козма Хазан, Поставен камен-темелникот на меморијалниот Центар на Холокаустот на Евреите (02.09.2005 година), Билтен за меѓународна соработка, бр. 5.

Алексиев Емил, Бронзена тивка и ненаметлива поетика, Дневник, 18 март 2006, бр 2719. http://star.dnevnik.com.mk/default.aspx?pbroj=2719\&stID $=51910$

Диран Жилбер, Симболичка имагинаичја, Сигмапрес, Скопје 2005.

17 Ж. Диран, Симболичка имагинација, Сигмапрес, Скопје 2005, p. 8. On the role of monuments see: Д. По п в в ка, Споменичните обележја од Втората светска војна во Македонија: идеолошка наративизација, Материјали од меѓународна научна конференција Балканот: луѓе, војни и мир, Скопје, 4-5 ноември, Универзитет Св. Кирил и Методиј, Институт за национална историја, Скопје 2015, $253-265$.

18 There are about 190 Jews remaining in the Republic of Macedonia at present. (Zh. Daskalovski, Remembering the Past, Central Europe Review, Vol. 2, No. 4, 31 January 2000. (date accessed: 08.05.2017). 
Дојчиноски Киро, Скопје-паралели, Матица Македонска, Скопје 1999.

Качева Алла, Христова Славица, Горѓиовска Татјана, Животот во Скопје 1918-1941, Музеј на град Скопје, Скопје 2002.

Коломонос Жамила, Весковиќ - Вангели Вера, Евреите во Македонија (1941-1945), Зборник на документи, том I, II, Македонска академија на науки и уметности, Скопје 1986.

Поповска Драгица, Музејот на холокаустот во Скопје: место на сеќавање, во Историја, Здружение на историчарите на PM, XLIX, 1, Скопје 2014.

Поповска Драгица, Споменичните обележја од Втората светска војна во Македонија: идеолошка наративизација, Материјали од меѓународна научна конференција Балканот: луѓе, војни и мир, Скопје, 4-5 ноември, Универзитет Св. Кирил и Методиј, Институт за национална историја, Скопје 2015.

Споменик на Евреите, Општина Штип,

http://stip.gov.mk/index.php/mk/profil/kultura/301-2009-12-10-10-16-28

Хаџи-Васиљевиќ Јован, Скопље и његова околина (историска, етнографска и културно-политичка излагаға), Штампарија „Св. Сава“, Београд 1930.

\section{Dragica Popovska}

\section{Symbolic Representations of Identity and the History of the Jews in Macedonia's Public Space}

\section{Summary}

With examples taken across the Republic of Macedonia, this paper investigates the symbolic representations of the Jews in Macedonia, i.e. "facilities" that express their identity and history and allow their visibility in the public space. I am speaking here not only for monuments and museums, but also for settlements and other symbols that created / create the image of Jews in Macedonia through time. The goal is to answer a few questions: What are the symbols that represent Jewish history and culture in the public sphere? What do these symbols tell us? What meanings or what emotions do they evoke in people? Of course, the discursive dimension of symbolic representations is very important, especially the socially constructed role which is attributed to those facilities. In accordance with these approaches, the identity construction as one of the key functions of symbolic representation, takes place within the social placed narratives of Jews, which means its dynamics and variables is directly related to social events, political changes, etc.

Key words: Macedonian Jews, public space, symbolic representation identity. 